\title{
24
}

\section{Pitfalls of Statutory Reform in Private Law: Recipient Liability for Breach of Trust}

\author{
Darryn Jensen
}

\section{Introduction}

Statutory law reform in relation to private law obligations has, historically, been mostly a matter of piecemeal adjustment rather than radical reconstruction. The piecemeal approach recognises the value in structures that have emerged gradually from case law. It seeks to resolve ambiguities or address concerns which arise in localised areas of the larger structure. Nevertheless, piecemeal statutory reform involves two risks. First, if there is inadequate reflection upon how the localised area of concern fits into the larger structure, the result may be to create a disjuncture between adjoining parts of the structure. Second, subsequent developments in the case law may render what was enshrined in statute redundant or nonsensical. Statute law in Western Australia and Queensland that was enacted primarily to remedy certain problems raised by the Diplock litigation ${ }^{2}$ has turned out to be a mixed blessing. It will be argued that the rules about the order of enforcement of claims against the trustee and 
recipients should be discarded and that case law developments in relation to the common law claim for money paid by mistake have resolved the central problem in the Diplock litigation.

\section{Recipient Liability for Breach of Trust}

Where someone receives a distribution of trust property and was not entitled to receive it, there are three types of equitable claim which the 'true' beneficiaries of the trust may bring against the recipient. First, if misappropriated trust funds can be traced into an asset, the beneficiaries may claim the asset or a share of the asset which is proportionate to the trust fund's contribution thereto. Whether the asset is legally owned by the trustee or a third party is irrelevant, except that a third party may be able to rely upon a defence of bona fide purchaser for value without notice. In Foskett v McKeown, ${ }^{3}$ Lord Millett observed that, in such a claim, the claimants 'seek to vindicate their property rights, not to reverse unjust enrichment'. ${ }^{4}$ This stance has been rationalised on the basis that, if a trustee has the power to make an effective transfer of trust assets, then 'any assets received in exchange are made subject to the same equitable interests as bound the original trust assets. ${ }^{5}$

Second, if a trustee conveys trust assets to, or confers an interest in trust assets on, a third party and the third party receives those assets or that interest knowing of the breach of trust, the third party will be liable in every way that the trustee would have been liable had the trustee been sued. ${ }^{6}$ Knowing receipt opens up the possibility that the recipient will be personally liable to restore the trust estate, so is potentially a more exacting

3 [2001] 1 AC 102.

4 [2001] 1 AC 102, 129. See also similar comments at 108 (Lord Browne-Wilkinson) and 115 (Lord Hoffmann).

5 R B Grantham and C E F Rickett, 'Property Rights as a Legally Significant Event' (2003) 62 Cambridge Law Journal 717, 747. Contrast Scott v Scott (1963) 109 CLR 649, 660 in which it was said that the proprietary order made at first instance (and ultimately upheld by the High Court) was based on the liability of the trustee 'to make good a breach of trust' and 'to account for a profit which accrued to him'. In Evans v European Bank Ltd (2004) 61 NSWLR 75, 103, the New South Wales Court of Appeal declined to clarify the basis for proprietary claims because it was not necessary to do so in order to decide the case before it.

6 The traditional formulation is that the recipient becomes a 'constructive trustee' (Barnes $v$ Addy (1874) LR 9 Ch App 244, 252). In Selangor United Rubber Estates Limited v Cradock (No 3) [1968] 1 WLR 1555, 1582, Ungoed-Thomas J explained that the defendant is liable in equity 'as though he were a trustee'. See also Lionel Smith, 'Constructive Trusts and Constructive Trustees' (1999) 58 Cambridge Law Journal 294, 300. 
form of recipient liability than that which results from a proprietary claim. Where a traceable asset in the recipient's hands does not represent the full value of the misappropriated trust assets, the recipient merely has to transfer the asset. There is no liability to compensate the trust estate for any shortfall arising from a depreciation of the traceable asset. ${ }^{7}$ Knowing receipt liability, on the other hand, is a true substitute for the beneficiaries' claim against the trustee.

Finally, it is conceivable that, where a trustee incorrectly distributes trust funds, a beneficiary or other person claiming through the trustee (such as a creditor of the trustee) ought to be able to recover from an innocent recipient the amount that the recipient received but should not have received. Equity is said to intervene in such a case because the recipient 'has received some share of the estate to which he was not entitled'. ${ }^{8}$ Re Diplock was a case about a deceased estate. The House of Lords, in dismissing an appeal, reasoned on the basis that this equitable claim was available against persons who had received distributions from deceased estates. ${ }^{9}$ Accordingly, it has been uncertain whether distributees of funds from inter vivos trusts are similarly liable. Lord Nicholls (writing extrajudicially) has suggested that a restriction to deceased estates, although explicable in historical terms, is irrational. ${ }^{10}$ In his Lordship's opinion, a claim should be available against a recipient from either type of trust estate 'to prevent what would otherwise be an unjust enrichment'. ${ }^{11}$ The recipient's liability is to make restitution of what it received and nothing more. This is a significant limitation because the loss suffered by the trust estate by reason of an unauthorised distribution will often be greater than the amount received by the unauthorised recipient. ${ }^{12}$

7 Where, in relation to a particular transaction in breach of trust, the plaintiffs elect to take the traceable asset rather than make a personal claim against the trustee for restoration of the trust estate, the traceable asset will be 'the full measure of relief available to them' (Scott v Scott (1963) 109 CLR $649,660)$.

8 [1948] Ch 465, 503.

9 Ministry of Health $v$ Simpson [1951] AC 251, 265. Lord Simonds remarked that 'the particular branch of the jurisdiction of the Court of Chancery with which [the case was] concerned relates to the administration of assets of a deceased person'.

10 Lord Nicholls, 'Knowing Receipt: The Need for a New Landmark' in W R Cornish, Richard Nolan, Janet O'Sullivan and Graham Virgo (eds), Restitution Past, Present and Future: Essays in Honour of Gareth Jones (Hart Publishing, 1998) 240-41.

11 Ibid. 237.

12 For example, as in Re Dawson [1966] 2 NSWR 211. See generally Jamie Glister, 'Breach of trust and consequential loss' (2014) 8 Journal of Equity 235. 
In Re Diplock, it was said that the amount recoverable was limited to the amount which could not be recovered from the trustee. ${ }^{13}$ In other words, the beneficiaries must recover what they can from the trustee before recovering any amount from the recipient. This restriction was supposed to be related to the equitable nature of the claim. The 'absence or exhaustion' of the beneficiaries' claim against the trustee was taken to be 'the justification for calling for equity to come to the aid of the law'. ${ }^{14}$ In Re Diplock, where the trustee had made the payments under a mistaken belief that a will provision was legally enforceable, there was no common law claim for money had and received, but the rule is clearly not concerned with the absence or exhaustion of that claim. It is concerned with the exhaustion of the claim against the trustee for restoration of the trust estate, which is an equitable claim. As Lord Nicholls remarked, the problem is 'internal to equity'. ${ }^{15}$

\section{Statutory Reform}

The Western Australian and Queensland statutory provisions do three things. First, they provide that a personal restitutionary claim of the Re Diplock type is available in all cases of incorrect distribution of trust property. ${ }^{16}$ Second, they create statutory change of position defences under which a recipient could, under certain conditions, be relieved of liability to repay the whole or part of what it received. ${ }^{17}$ These reforms were justified. There is nothing in the rationale of the personal restitutionary claim that demands that it be confined to cases involving deceased estates. The change of position defence is welcome because recipients who have disbursed the funds that they received may suffer hardship if required to repay.

Third, and more contentiously, the statutes set down rules about the order of enforcement of claims against the trustee and claims against recipients. The Western Australian legislation reverses the Re Diplock order of enforcement. No remedy may be enforced against the trustee until the beneficiary has exhausted 'all other remedies available to him, whether

13 [1948] Ch 465, 503.

14 [1948] Ch 465, 503-4; see also Ministry of Health v Simpson [1951] AC 251, 266.

15 Lord Nicholls, above n 10, 241.

16 Trustees Act 1962 (WA) s 65(1); Trusts Act 1973 (Qld) s 113(1).

17 Trustees Act 1962 (WA) s 65(8); Trusts Act 1973 (Qld) s 113(3). 
under this section or in equity or otherwise. ${ }^{18}$ This language clearly encompasses claims to traceable assets held by recipients, knowing receipt or assistance claims and personal restitutionary claims against recipients. ${ }^{19}$ The Queensland Law Reform Commission took the view that there was 'no virtue whatever in placing the primary responsibility for a wrongful distribution on the distributee'. ${ }^{20}$ Accordingly, the Queensland legislation affirms the rule stated in $\operatorname{Re}$ Diplock, ${ }^{21}$ so that the personal restitutionary claim against the recipient cannot be enforced until all remedies, personal and proprietary, against the trustee have been exhausted. ${ }^{22}$

\section{The Pitfalls of Reform}

\section{A. Order of enforcement of claims}

The Queensland provision emphasises the trustee's culpability in respect of the incorrect distribution. The trustee should be primarily responsible for putting things right. This premise is open to challenge. Certainly, the culpability of the executor in Re Diplock was of the slightest variety. The executor had acted in accordance with the terms of the will. The executor's mistake was simply to assume that the relevant clause of the will was legally enforceable when it was not. A conclusion that such a trustee should always bear the burden of restoring the trust estate ahead of a recipient who has made a windfall gain is questionable.

The greater difficulty is that recipients, unless they are knowing recipients, are not liable to restore the trust estate. Their liability is limited to the value of what they have received. Under the Queensland provision, the recipient is liable to give back only so much of what it received as is necessary to make up for the trustee's inability to restore the trust estate in full. If, on the other hand, Lord Nicholls is correct is saying that the Re Diplock claim 'presupposes that the recipient was enriched by a windfall

18 Trustees Act 1962 (WA) s 65(7)(b).

19 Corporate Systems Publishing v Lingard (No 4) [2008] WASC 21, [184]. Beech J described the prerequisite to enforcement of a judgment against a trustee as 'any judgment against the recipients or assisters is satisfied'. See also Peter Creighton and Elise Bant, 'Recipient Liability in Western Australia' (2000) 29 Western Australian Law Review 205, 229.

20 Queensland Law Reform Commission, Report on the Law relating to Trusts, Trustees, Settled Land and Charities (QLRC 8) (1971) 74.

21 Trusts Act 1973 (Qld) s 113(2).

22 Ron Kingham Real Estate Pty Ltd v Edgar [1999] 2 QdR 439, 445 (McPherson JA). 
gain', ${ }^{23}$ a requirement that claims against the trustee be exhausted first does not harmonise with the rationale for making the recipient liable. The recipient should be liable to give back what it received regardless of the trustee's means to restore the trust estate. The rule that claims against the trustee must be exhausted first protects a recipient on the basis of the happy circumstance that the trustee has the resources to restore the trust estate.

Equally, it is not clear that a trustee should be relieved of liability to the extent that the trust estate can be restored by recovering what has passed into the hands of third parties or, where there is a knowing recipient, by making the recipient personally liable to restore the trust estate. Under the Western Australian legislation, the difference between cases in which remedies can be enforced against trustees and those in which they cannot be is the happy circumstance that third parties have either traceable assets or sufficient monetary resources to pay back the amounts that they received. Where a third party is a knowing recipient, that third party is jointly and severally liable to restore the trust estate on account of the third party's culpability in respect of the breach of trust being as great as that of the trustee, but the third party is not necessarily any more culpable than the trustee. Of course, it may be convenient for a plaintiff to enforce first any of the remedies against third party recipients on the basis that it is easy to do so compared to requiring the trustees to restore the trust estate using their own resources, but it is difficult to see any principled justification for requiring plaintiffs to do so. Creighton and Bant have remarked that it would be 'preferable simply to eliminate any requirement for exhaustion of remedies. ${ }^{24}$

\section{B. Redundancy}

In Re Diplock, the beneficiaries had to rely upon equity to found their restitutionary claim against the recipients because a common law claim would not have been available. At the time, it was generally believed that a common law action for money had and received was not available where the payer's mistake was a mistake as to the law. The 'mistake' in Re Diplock

23 Lord Nicholls, above n 10, 241.

24 Creighton and Bant, above n 19, 230. In 2013, the Queensland Law Reform Commission recommended that the requirement that remedies against the trustee should be exhausted before enforcing remedies against recipients should be removed (Queensland Law Reform Commission, Review of the Trusts Act 1973 (QLRC 71) (2013) 129). At the time of writing, subs 113(2) remained unamended. 
was an assumption that the provision of the will under which the payments were made was legally enforceable. The provision was unenforceable because the trustee's discretion to choose recipients encompassed entities that did not have charitable purposes. This was a mistake as to law.

By the end of the 1990s, in both England and Australia, it had been recognised that money paid under a mistake of law is recoverable by way of a common law action. ${ }^{25}$ In so far as situations involving receipt of funds from trustees fall within the scope of a general common law rule that demands the restitution of mistaken payments, then the equitable claim would be redundant. Equity operates on the basis that the common law is inadequate to do justice, rather than on the basis that the payer is a trustee. The common law claim applies to all recipients. It is not restricted to funds received from deceased estates. A plaintiff who relies on the common law claim would not have to exhaust any remedies that are available against the trustee before enforcing the claim. It has become clear that a defendant recipient would, in appropriate cases, be able to invoke a common law change of position defence. ${ }^{26}$

The proper plaintiff in a claim for money had and received against the recipient of trust funds is the payer of the funds - that is, the trustee. A beneficiary is not normally entitled to bring an action in place of the trustee, but it is clear that a beneficiary could bring a derivative action against a debtor of the trustee if the action 'is needed to avoid injustice. ${ }^{27}$ It has been argued that a beneficiary may bring a derivative action where the trustee 'unjustifiably fails to bring an action to protect the trust'. ${ }^{28}$ The trustee would be obliged to recover the incorrect distribution from the recipient. This would be an aspect of the trustee's duty to restore the trust estate. Beneficiaries could compel the trustee to bring the action, so the derivative action simply aggregates the beneficiary's action to compel the trustees to recover the debt and the trustee's action against the recipient. ${ }^{29}$ The cumulative effect of the abrogation of the fact/law

25 David Securities Pty Ltd $v$ Commonwealth Bank of Australia (1992) 175 CLR 353; Kleinwort Benson Ltd v Lincoln City Council [1999] 2 AC 349.

26 Port of Brisbane Corporation v ANZ Securities Limited [2002] QCA 158, [27]; Alpha Wealth Financial Services Pty Ltd v Frankland River Olive Company Limited [2008] WASC 119, [196]-[211]; Australian Financial Services and Leasing Pty Limited v Hills Industries Limited [2014] HCA 14.

27 Roberts $v$ Gill \& Co [2010] UKSC 22, [110] (Lord Collins).

28 Emma Hargreaves, 'The Nature of Beneficiaries' Rights under Trusts' (2011) 25 Trust Law International $163,178$.

29 H A J Ford and W A Lee, Principles of the Law of Trusts (Thomson Reuters, Sydney, $4^{\text {th }}$ edn, 2010) [17.4110]. 
distinction and the availability of derivative actions is that beneficiaries can bring common law claims to recover the funds incorrectly distributed. Therefore, statutory provisions which entrench the Re Diplock claim as part of the law and set down prerequisites to its enforcement might be seen to be redundant. ${ }^{30}$

\section{Conclusion}

To preserve the Western Australian and Queensland statutory provisions on recipient liability in their current form is to retain unnecessary complication and to invite confusion. It is time for the content and form of these provisions to be reconsidered. There should be a shift from prescribing the order of enforcement to allowing plaintiffs to choose the order in which remedies are enforced, subject to a provision that the total amount recovered by way of personal claims against the trustees and recipients should not exceed the total amount required to restore the trust estate.

30 Ibid. [17.7010]. Ford and Lee observed that 'these provisions, while they still may be of some procedural value, are no longer needed'. 
This text is taken from New Directions for Law in Australia: Essays in Contemporary Law Reform, edited by Ron Levy, Molly O’Brien, Simon Rice, Pauline Ridge and Margaret Thornton, published 2017 by ANU Press, The Australian National University, Canberra, Australia. 